\title{
Viewing the Ideological Education of Different Countries from the Comparative Study of Chinese and American Primary and Secondary School Textbooks
}

\author{
Boya Zhang ${ }^{1 *}$
}

\author{
${ }^{1}$ Jilin University, Changchun 130000, Jilin, China \\ *Corresponding author. Email:1069346730@qq.com
}

\begin{abstract}
Textbooks are the main carrier of national ideology infiltration, and play an important role in maintaining the stability of state power, correctly positioning the country's image, and reflecting the will of the country. This article intends to analyze the ideological education of different countries through a comparative study of Chinese and American elementary and middle school textbooks, and put forward the hope that different countries' ideological education can remove inherent "prejudice" and "political favoritism" in mutual learning, expecting to have a positive impact on the ideological education of different countries in the world for the new generation in the future.
\end{abstract}

Keywords: Ideology, pedagogy, political science, textbook, America, China, educational difference

\section{INTRODUCTION}

Ideology is the cornerstone of the stability of a country's political system, and it is vital to maintaining the stability of a country. In order to maintain its own political power and its dominant position, the ruling party must use ideological resources to propagate and instill the ideas of its own class through various channels, so as to form a social mindset and behavioral norms to ensure the long-term stability of the society. School education is the most direct and most important channel for the state apparatus to instill and spread ideology, and textbooks are the key to the state apparatus's ideological tool in the construction of identity. Based on the above considerations, this article attempts to further explore the topic of "ideological education in different countries" through a comparative study of Chinese and American primary and secondary school textbooks. It is hoped that this research can help strengthen and improve the ideological education of the new generation of different countries in the world. On the basis of elaborating the importance of ideology and textbooks, this article analyzes and compares the differences in the textbook selection system between China and the United States, the similarities and differences in textbook content, and the differences in the mainstream awareness education methods in textbooks, and proposes the correct methods and approaches for countries in the world to conduct mainstream ideological education.

\section{SELECTION SYSTEM OF TEXTBOOKS}

As a part of the social system, the textbook system is compatible with the political, economic, cultural and educational traditions of various countries. From a global perspective, there are five main types of textbook recognition and adoption systems: national customization, review customization, certification system, optional customization and free system. The right to select textbooks generally has four types of ownership: teachers; the principal; the cooperation of the teacher principal; the local education administration department or the school district education board. In the actual situation, any country does not only adopt one of the above, but more adopts a mixed system, that is, the right to choose textbooks is shared by the above-mentioned subjects.

\subsection{China's Textbook Selection System}

The textbook selection system in China has gradually transitioned from national customization to review customization, that is, the transition from the national or local education administrative department deciding what textbook system to use to privately written books must be reviewed and qualified by the 
national or local education administrative department before they can be published as textbooks issued. In China, textbooks are usually selected by the education department, school, and teachers.

\subsection{The Textbook Selection System in the United States}

Different U.S. states have different textbook selection systems. 27 U.S. states including Alabama, South Carolina, and Texas adopt optional customization, that is, the national or local education administration department selects several textbooks in various subjects and makes a list for each school district or school select. And 15 other states in the United States implement a liberal system, that is, not only is the publication and distribution of textbooks completely free, but the use of textbooks is also determined by the school district or school without the approval of the higher education administration. In addition, there are 10 states in the United States that choose to choose custom and free systems in parallel.

With the continuous development of the textbook system, the current development trend of the textbook system in China and the United States is: continuous decentralization of powers in customized countries, introducing competition mechanisms, giving teachers and students more rights, and expecting to establish a relatively free textbook system. And liberal countries have also begun to strengthen the state's control over textbooks. Both China and the United States are developing in the direction of textbook diversification, democratization, scientification, and legalization.

\section{DIFFERENT INDOCTRINATION OF IDEOLOGY IN CHINESE AND AMERICAN TEXTBOOKS}

\subsection{The Similarities and Differences of Mainstream Ideological Education Content in Chinese and American Textbooks}

\subsubsection{Similarities}

Both China and the United States focus on ideological education in the textbooks of history, politics and literature. For the history subject, construct the "collective memory" and "common memory" of the educated in the textbook, and form the national identity through historical identification [1]; for the political subject, the textbook compiles the political system of the country in detail. The introduction, while comparing with the political systems of other countries in the world, praises the superiority of the political system of the country, achieves the mainstream ideology, political beliefs, and political personality consistent with the country, and maintains the mainstream values and world outlook of the ruling party[2]; for literary disciplines, include classic literary works in line with the mainstream ideology of the country in textbooks, and construct the "identity" of the educated through article reading and textbook teaching guidelines, so as to achieve an important role in reproducing the ideology of the ruling class.

\subsubsection{Differences}

China is an ancient country with more than 5,000 years of civilized history. It has made brilliant achievements ahead of the world, and has experienced more than 100 years of humiliation and backwardness in modern times. It needs to overcome the double erosion of feudal and capitalist ideas, especially in the ideological field. The cultural soft power of a country, fundamentally speaking, depends on the vitality, cohesion, and appeal of its core values. Cultivation and promotion of core values and effective integration of social awareness are important ways for the normal operation of the social system and effective maintenance of social order. It is also an important aspect of the national governance system and capabilities. Both history and reality show that the construction of core values with strong charisma is related to social harmony and the country's long-term stability. At the current stage, in the face of the globalization of the world economy, cultural diversification, and world-wide ideological and cultural exchanges, the new situation of value contests, the Communist Party of China has put forward the "core values of socialism", which are called "soft culture" in China, the soul of strength and the focus of cultural soft power construction".[3] The core values of socialism can be divided into three levels. Prosperity, democracy, civilization, and harmony are the value goals at the national level. Freedom, equality, justice, and the rule of law are the value orientations at the social level, and patriotism, dedication, integrity, and friendliness are the values of the individual citizens. The core values of socialism will serve as the internal benchmark for textbooks to shape the image of China for a long time, and it is also the basis for a critical dialogue with cross-cultural understanding of the image of "other countries" in other ideological fields.

For the United States, although the mainstream ideological education in American schools is rich in content and can be continuously adjusted and updated according to the development of American politics, economy, culture and society, its main content is still capitalist ideology, that is, humanism.[4]Thinking as the foundation and ensuring the development of individuality and individual interests as the core value, this is also the standard that Americans generally agree and internalize as value judgments and behave in the world. 
American schools use various methods to educate students on ideology. First of all, in the content setting of textbooks and after-school activities, students are guided to actively care about and participate in politics, so that students understand national politics and identify with the American political system. Secondly, through religious propaganda, ideological propaganda and infiltration of students. Religion is an important means of spreading ideology for Western countries. [5]After long-term development, religious doctrines have been consistent with the mainstream ideology of capitalist society and have become a means to consolidate and maintain rule. The combination allows students to experience emotional experience in various social practices, gain empirical cognition, and subtly spread the "American spirit" into the hearts of students, so that they naturally generate a sense of identity and pride for the country and the nation, and firmness I agree and support the American social system and social requirements.[6]Therefore, through the conduct of these courses and activities, the mainstream ideology of the United States is passed on, namely the "American spirit" of American values, the superiority of the capitalist system, and the education of civil rights and obligations. It has played a huge role in maintaining the American capitalist system, promoting social stability and development, and cultivating qualified citizens and bourgeois successors.

\subsection{Differences in Mainstream Ideological Education Methods in Chinese and American Textbooks}

The mainstream ideological education methods in Chinese textbooks are relatively single. Although there are dialectical teaching methods and thinking modes such as "one lesson, one question" and "thinking questions" in textbooks, it is more about instilling knowledge. Through the "instillation" of textbooks, teachers set up teaching in the classroom. [7]It also had to become "predictive", confined to the pure theoretical teaching of books, lack of communication and interaction with students, lack of sincere emotional and rational inspiration, such a teaching method easily incurs students' boredom and disgust. The effect is thus greatly reduced.

American textbooks usually comprehensively use moral dilemma discussion method, value clarification method and social learning method to carry out mainstream ideological education. Teachers guide and discuss accordingly in the classroom, and to stimulate students' dialectical thinking, the combination of theory and practice, so that students can explore and practice spontaneously, so as to have a spontaneous heart recognition of the ideology transmitted by the school, which is not easy to arouse the students' rebellious psychology, and is easier to accept. It enables students to spontaneously produce "American spirit" and "American value" to achieve their fundamental educational goals.

\section{CONCLUSION}

The article first expounds on the importance of ideological education for maintaining the stability of state power, and analyzes the full text through textbooks, a powerful tool for ideological education in various countries. In the first section, the author analyzes the textbook selection systems and methods in China and the United States through the textbook selection system in the world, and concludes that as the globalization of the world continues to accelerate, the textbook systems of China and the United States are both prospering in the direction of diversification, democratization, scientification, and legalization. In the second section, the author looks at the similarities and differences of different ideological educations between China and the United States through textbooks. First, it analyzes the similarities between the two countries, that is, mainly ideological education for students through the three disciplines of politics, history and literature. Secondly, it analyzes the differences in ideological education between the two countries, that is, due to the differences in political and economic systems and ideological culture between China and the United States, there are many differences in mainstream ideological education in Chinese and American schools. Although the ideological and political education of China and the United States have essential differences in ideology, the educational laws embodied in the different educational mechanisms, educational methods, and educational content of the two countries can learn from each other and put forward the hope that different countries' ideological education can remove inherent "prejudice" and "political favoritism" in mutual learning, in order to achieve a better, more harmonious and fair human spiritual home.

A textbook is a tool to reproduce the ideology of the ruling class. Its content is composed of the ruling class chooses knowledge suitable for its ruling needs basing on its legitimacy. The knowledge of textbooks is statutory knowledge, and the writers, reviewers, and users of textbooks are legal spokespersons dispatched by the ruling class. The content of the text reflects mainstream values and is a legal culture. It is an excellent target for investigating knowledge and power, society and political system. Through the internalization and penetration of textbooks, young people gradually become accustomed to the mainstream culture in their hearts. What it shows is that it will consciously or unconsciously maintain the mainstream ideology in thinking, language, and behavior, thereby maintaining the country's "united stability" and achieving the goal of ruling the ruling class.[8] 
With the accelerating process of economic globalization, cultural diversification, and world integration, the world has continuously become a "global village", and the realization of a community with a shared future for mankind will surely become a reality in the near future. The author hopes that this research will be helpful to the ideological education of the new generation in different countries and political systems in the world. Although different political systems have a strong "ideological nature" in the interpretation of ideology itself, and textbooks are used to maintain national ideological security and socialize mainstream ideology, the author hopes that the country will educate the new generation in the process of ideological education. It can remove the "prejudice" and "political favoritism" contained in the political system of the country, and explain the facts more objectively, so that the new generation can recognize, understand and analyze the world from a critical and dialectical perspective and better find a balance in the political system in today's multi-polar world, which is not only conducive to the peaceful, prosperous, and stable development of society, the country, and the world, but in the long run, it also contributes to the construction of a happy and harmonious human home and a great human civilization.

\section{ACKNOWLEDGMENT}

First of all, I am very grateful to my instructor, the professor, for his careful guidance of my thesis during the course and after class, which greatly improved my understanding of academic writing and taught me many specific research skills. Knowledge is a vast ocean, insignificant I am just a small boat, thank the teachers who gave me selfless help, so that I can get a glimpse of the vast ocean; thank you dear classmates who gave me care and support, with you, I can better complete the thinking and creation of the thesis, so that I can combine the knowledge of multiple disciplines to view and think about the world more rationally, objectively and dialectically!

\section{REFERENCES}

[1] Yan, F; Zhong, Z; Wang, HN; Wen, Q. (2019) Grafting identity: History textbook reform and identity-building in contemporary China, JOURNAL OF EDUCATIONAL CHANGE

[2] Zhong, MH; Zhang, J.(2015) Analysis of the citizenship education of China's junior high school stage, ASIAN EDUCATION AND DEVELOPMENT STUDIES, 4:190-203

[3] Zhan, WS; Ning, WJ (2004) The moral education curriculum for junior high schools in 21st century China, JOURNAL OF MORAL EDUCATION, $33: 511-532$
[4] You, XY (2005) Ideology, textbooks, and the rhetoric of production in China, COLLEGE COMPOSITION AND COMMUNICATION, 56:632-653

[5] ANYON, J (1979) IDEOLOGY AND UNITED-STATES HISTORY TEXTBOOKS, HARVARD EDUCATIONAL REVIEW, 49:361-386

[6] Bendix, R. 1969. Nation-building and citizenship: Studies of our changing order. New York: Doubleday

[7] Chen, L.F. (trans). 1988. The confucian way. London: Kegan Paul International

[8] Weber, M. 1951. The religion of China. New York: The Free Press 